\title{
Temporary stabilization of air pollution control residues using carbonation
}

\author{
Hua Zhang ${ }^{\mathrm{a}}$, Pin-Jing He ${ }^{\mathrm{a}, *}$, Li-Ming Shao ${ }^{\mathrm{a}}$, Duu-Jong Lee ${ }^{\mathrm{b}}$ \\ ${ }^{a}$ State Key Laboratory of Pollution Control and Resources Reuse, Tongji University, Shanghai 200092, China \\ ${ }^{\mathrm{b}}$ Chemical Engineering Department, National Taiwan University, Taipei 10617, Taiwan, ROC
}

Accepted 5 February 2007

Available online 3 April 2007

\begin{abstract}
Carbonation presents a good prospect for stabilizing alkaline waste materials. The risk of metal leaching from carbonated waste was investigated in the present study; in particular, the effect of the carbonation process and leachate $\mathrm{pH}$ on the leaching toxicity of the alkaline air pollution control (APC) residues from municipal solid waste incinerator was evaluated. The $\mathrm{pH}$ varying test was conducted to characterize the leaching characteristics of the raw and carbonated residue over a broad range of $\mathrm{pH}$. Partial least square modeling and thermodynamic modeling using Visual MINTEQ were applied to highlight the significant process parameters that controlled metal leaching from the carbonated residue. By lowering the $\mathrm{pH}$ to $8-11$, the carbonation process reduced markedly the leaching toxicity of the alkaline APC residue; however, the treated APC residue showed similar potential risk of heavy metal release as the raw ash when subjected to an acid shock. The carbonated waste could, thereby, not be disposed of safely. Nonetheless, carbonation could be applied as a temporary stabilization process for heavy metals in APC residues in order to reduce the leaching risk during its transportation and storage before final disposal.
\end{abstract}

(c) 2007 Elsevier Ltd. All rights reserved.

\section{Introduction}

Carbonation has been recognized to be an important process affecting alkaline materials (waste) such as bottom ash from municipal solid waste incinerators (MSWI) and cement-stabilized waste (Chimenos et al., 2000; Garrabrants et al., 2004; Gervais et al., 2004; Meima et al., 2002; Van Gerven et al., 2005; Walton et al., 1997). It has also been proposed as a means to stabilize $\mathrm{Pb}$ and $\mathrm{Zn}$ in air pollution control (APC) residues from MSWI (Bone et al., 2003; Ecke et al., 2003a; Kim et al., 2003). The effect of carbonation on the leaching toxicity of these samples was intensively investigated (Freyssinet et al., 2002; Meima and Comans, 1998; Polettini and Pomi, 2004; Van Gerven et al., 2004, 2005; Yu et al., 2005), which could be summarized as: (1) lowering $\mathrm{pH}$ of the leachate;

\footnotetext{
${ }^{*}$ Corresponding author. Tel./fax: +86 2165986104.

E-mail address: solidwaste@mail.tongji.edu.cn (P.-J. He).
}

(2) changing the metal solubility due to precipitation of metal carbonates or formation of oxyanions $(\mathrm{Cr}$ and $\mathrm{Mo})$; (3) reducing release of certain metals $(\mathrm{Cu}$ and $\mathrm{Mo})$ by sorption to the neoformed minerals (in 1.5-year weathered bottom ash); and (4) decreasing the matrix porosity because of the formation of calcite.

However, certain leaching results have been interpreted based on single batch tests, which may obtain discrepant results (Astrup et al., 2006; Li et al., 2001). Detailed leaching behavior of uncarbonated and carbonated ash has been investigated using $\mathrm{pH}$ varying test or semi-dynamic leaching tests (Garrabrants et al., 2004; Meima et al., 2002; Van Gerven et al., 2005, 2006); most of these tested samples were bottom ash or cement-stabilized ash. Leaching behavior of carbonated APC residues without cement stabilization is rarely discussed. Furthermore, it is inconclusive whether the change in metals retention properties are due to the precipitation of metal-carbonates as some researchers have suggested (Bone et al., 2003; Freyssinet et al., 2002) or to a shift in pore water $\mathrm{pH}$ as a result of 
carbonation which changed the solubility of metals (Sanchez et al., 2002; Van Gerven et al., 2004). Therefore, the effects of environmental change on the leaching potential of carbonated APC residues have not been satisfactorily explored.

To address these problems, a previous study (He et al., 2006a) examined the leaching behaviors of the APC residue during the natural aging process evaluated by three kinds of regulatory leaching tests. It was demonstrated that both leaching tests and carbonation substantially affected the leaching results. Model calculations based on the geochemical thermodynamic equilibrium model MINTEQA2 suggested that the formation of metal carbonates did not correspond to the noted change in the leaching behaviors. Rather, the partial neutralization of alkaline ash by dissolved $\mathrm{CO}_{2}$, lowering the final $\mathrm{pH}$ of the leachate, dominated the leaching characteristics. Metals immobilized by carbonation will be released again under an acidic environment. However, the experimental proof to demonstrate this proposal remained preliminary.

This work is different from He et al. (2006a) in the following three aspects. (1) The $\mathrm{pH}$ varying test was conducted over $\mathrm{pH}$ 0.4-12.9 to demonstrate the leaching characteristics of raw and carbonated samples. (2) Effects of carbonation were analyzed using partial least square (PLS) modeling (Umetrics AB, 2005) of experimental data and using thermodynamic modeling, Visual MINTEQ (Allison et al., 1991; Gustafsson, 2005), considering redox reactions for illustrating the impact of carbonation on leaching characteristics. (3) Based on the experimental findings, the use of waste carbonation as a temporary pretreatment process for heavy metal stabilization was proposed.

\section{Methods and materials}

\subsection{Residues}

The APC residue samples were collected from the flue gas treatment units of a MSW incineration plant (mass burn) with a treatment capacity of approximately $1200 \mathrm{t} /$ $\mathrm{d}$ in Shanghai City, China, equipped with a semi-dry reactor with lime slurry injection, activated carbon adsorption, and bag filters to remove acid gas, heavy metals, dioxins, and particulate matter, respectively. Table 1 lists the chemical compositions of the raw residue. Due to the presence of

Table 1

Raw APC residue composition

\begin{tabular}{llll}
\hline Major components & Content (wt.\%) & Trace elements & Content $(\mathrm{mg} / \mathrm{kg})$ \\
\hline $\mathrm{Ca}$ & $30 \pm 1.4$ & $\mathrm{As}$ & $71 \pm 1.5$ \\
$\mathrm{~K}$ & $3.2 \pm 0.04$ & $\mathrm{Cd}$ & $57 \pm 0.2$ \\
$\mathrm{Na}$ & $2.9 \pm 0.04$ & $\mathrm{Cr}$ & $450 \pm 21$ \\
$\mathrm{Fe}$ & $3.0 \pm 0.07$ & $\mathrm{Cu}$ & $980 \pm 19$ \\
$\mathrm{Mg}$ & $1.4 \pm 0.02$ & $\mathrm{Hg}$ & $39 \pm 4.2$ \\
$\mathrm{Cl}^{-}$ & $9.4 \pm 0.10$ & $\mathrm{Ni}$ & $130 \pm 2.0$ \\
$\mathrm{SO}_{4}^{2-}$ & $1.5 \pm 0.03$ & $\mathrm{~Pb}$ & $2620 \pm 60$ \\
$\mathrm{CO}_{3}^{2-}$ & $1.4 \pm 0.14$ & $\mathrm{Zn}$ & $5400 \pm 140$ \\
$\mathrm{PO}_{4}^{3-}$ & $<0.001$ & $\mathrm{Mn}$ & $1000 \pm 5$ \\
\hline
\end{tabular}

a semi-dry process unit, calcium was the most abundant element in the APC residue. Moreover, the residue was composed of $\mathrm{Cl}^{-}, \mathrm{K}, \mathrm{Na}, \mathrm{Fe}, \mathrm{Mg}, \mathrm{SO}_{4}^{2-}$, and $\mathrm{CO}_{3}^{2-}$. The concentrations of trace elements followed the order: $\mathrm{Zn}>\mathrm{Pb}>\mathrm{Cu}>\mathrm{Cr}>\mathrm{Ni}>\mathrm{Cd}>\mathrm{As}>\mathrm{Hg}$.

The raw APC residue was mixed with distilled water to make a sample of $20 \mathrm{wt} . \%$ moisture content, which was fed into two columns $(\Phi 5 \mathrm{~cm} \times 25 \mathrm{~cm})$, with a 500 -g residue sample in each. In column 1 , the residue was carbonated at accelerated rates by flowing through pure $\mathrm{CO}_{2}$ at a rate of $0.4 \mathrm{~m}^{3} / \mathrm{h}$ for $10 \mathrm{~h}$ (rapidly carbonated). In column 2 , air $\left(0.03 \% \mathrm{v} / \mathrm{v} \mathrm{CO}_{2}\right)$ was flowing through at $0.4 \mathrm{~m}^{3} / \mathrm{h}$ for 7 days to simulate a normal aging process (slowly carbonated).

The amounts of carbonate $\left(\mathrm{CO}_{3}^{2-}\right)$ in raw, rapidly and slowly carbonated residues were measured by mixing $1 \mathrm{~g}$ of residue with $10 \mathrm{ml}$ of $1 \mathrm{~mol} / 1 \mathrm{HNO}_{3}$, and then analyzing the $\mathrm{CO}_{2}$ gas release using a gas chromatograph $(\mathrm{GC102}$, Shanghai Analytical Instrument Overall Factory, China).

\subsection{Leaching test}

Leaching tests were conducted based on a regulatory leaching test (State Environmental Protection Administration of China, 1997); $100 \mathrm{~g}$ of each residue sample (raw, rapidly and slowly carbonated) was mixed with 11 of distilled water (liquid to solid ratio, $\mathrm{L} / \mathrm{S}=10 \mathrm{l} / \mathrm{kg}$ ) and tumbled at $30 \pm 2 \mathrm{rpm}$ for $18 \mathrm{~h}$. The mixture was vacuumfiltered through a $0.45-\mu \mathrm{m}$ membrane. The leachate $\mathrm{pH}$ and ORP were recorded and the concentrations of $\mathrm{Cd}$, $\mathrm{Cr}, \mathrm{Cu}, \mathrm{Ni}, \mathrm{Pb}$ and $\mathrm{Zn}$ in the filtrate were then analyzed using an atomic absorption spectrophotometer (AAS), while those of As and $\mathrm{Hg}$ were analyzed using an atomic fluorescence spectrometer (AFS).

The $\mathrm{pH}$ varying test was carried out to determine the $\mathrm{pH}$-dependent leaching behavior of the residues (van der Sloot et al., 1997). The raw residue sample was equally divided into 15 parts, each of 30 -g by weight, which were extracted individually for $48 \mathrm{~h}$ by using $300-\mathrm{ml}$ of $\mathrm{NaOH}$ solutions of $0.5,0.2,0.1,0.05 \mathrm{~mol} / 1$, distilled water, and $\mathrm{HNO}_{3}$ solutions of concentrations of $0.1,0.2,0.4,0.6$, $0.8,1.0,1.2,1.5,1.8$, and $2.0 \mathrm{~mol} / 1$, respectively. A similar extraction procedure was adopted to the rapidly and slowly carbonated residues; however, they were each divided into only 10 parts, which were individually extracted by using $\mathrm{NaOH}$ solutions of concentrations of $0.5,0.2,0.05 \mathrm{~mol} / \mathrm{l}$, distilled water, and $\mathrm{HNO}_{3}$ solutions of $0.2,0.4,0.5,0.6$, $0.8,1.0 \mathrm{~mol} / \mathrm{l}$, respectively. The final $\mathrm{pH}$ and the metal concentrations in the filtrates were measured.

The variability of $\mathrm{Hg}$ and As concentration in duplicates was within $10 \%$, and other heavy metals concentration within $3 \%$.

\subsection{Leaching modeling}

Solubility of carbonates is greatly dependent on leachate pH. Therefore, Visual MINTEQ was applied herein to 
determine the chemical stability of pure metal carbonates as a function of $\mathrm{pH}$, by solely inputting the metal carbonates as finite solid.

The equilibrium species of metals and As leached from the real carbonated samples were also modeled, by inputting in Visual MINTEQ the aqueous ion concentrations, and the $\mathrm{pH}$ and Eh values $(-18 \mathrm{mV}$ for slowly carbonated ash and $70 \mathrm{mV}$ for rapidly carbonated ash) measured in the regulatory leaching test, allowing precipitation/dissolution, redox, aqueous complexation reactions. The input molar concentrations for each component $\left(\mathrm{Al}^{3+}\right.$, $\mathrm{Ca}^{2+}, \mathrm{Cd}^{2+}, \mathrm{Cr}(\mathrm{OH})_{2}^{+}, \mathrm{Cu}^{2+}, \mathrm{Fe}^{3+}, \mathrm{H}_{3} \mathrm{AsO}_{4}, \mathrm{Hg}_{2}^{2+}$, $\mathrm{H}_{4} \mathrm{SiO}_{4}, \mathrm{Mg}^{2+}, \mathrm{Mn}^{2+}, \mathrm{Ni}^{2+}, \mathrm{Pb}^{2+}, \mathrm{Zn}^{2+}, \mathrm{Cl}^{-}, \mathrm{CO}_{3}^{2-}$, $\mathrm{SO}_{4}^{2-}, \mathrm{PO}_{4}^{3-}$ ) were based on the determined total amount (Table 1) divided by the $\mathrm{L} / \mathrm{S}$ ratio 10 and the molar mass of the component. The input redox couples included $\mathrm{H}_{3} \mathrm{AsO}_{3} / \mathrm{AsO}_{4}^{3-}, \mathrm{Cr}(\mathrm{OH})_{2}^{+} / \mathrm{CrO}_{4}^{2-}, \mathrm{Cr}^{2+} / \mathrm{Cr}(\mathrm{OH})_{2}^{+}, \mathrm{Cu}^{+} /$ $\mathrm{Cu}^{2+}, \mathrm{Fe}^{2+} / \mathrm{Fe}^{3+}, \mathrm{Hg}_{2}^{2+} / \mathrm{Hg}(\mathrm{OH})_{2}, \mathrm{HS}^{-} / \mathrm{SO}_{4}^{2-}$. The $\log \mathrm{K}$ value of $\mathrm{Pb}(\mathrm{OH})_{2}$ concentration was taken as -10.15 , from van der Bruggen et al. (1998). The other $\log K$ values referred to the default values in Visual MINTEQ. This work disregards the role of gas phase and surface complexation/precipitation (Eighmy et al., 1995; van der Bruggen et al., 1998; van Herck et al., 2000). The temperature in calculations was set at $25^{\circ} \mathrm{C}$.

\subsection{Multivariate data analysis}

PLS modeling was used to highlight the inter-relationships between three process parameters (factors), being extractant concentrations (negative for alkaline and positive for acid solution), extent of carbonation (rapid or slow, denoted by carbonate content), and leachate $\mathrm{pH}$, on the leaching behavior (response variables).

\section{Results}

\subsection{Stabilization of heavy metals and As in the APC residue using carbonation}

During carbonation, $\mathrm{CO}_{2}$ was absorbed and reacted with alkaline compounds in the residue. After $10 \mathrm{~h}$ of rapid carbonation, the $\mathrm{CO}_{3}^{2-}$ content in the residue increased from $1.43 \mathrm{wt} . \%$ to $8.85 \mathrm{wt} . \%$, comparable to the result of 7.2 wt. \% in Van Gerven et al. (2005), and the leachate $\mathrm{pH}$ (extracted by distilled water at $\mathrm{L} / \mathrm{S}=10 \mathrm{l} / \mathrm{kg}$ ) decreased from 12.0 to 8.7 (Fig. 1), which was comparable to the carbonation level of natural aging for more than 1 month (He et al., 2006a). Slow carbonation for 7 days, however, obtained a lower carbonation level, revealed by the low $\mathrm{CO}_{3}^{2-}$ content of $4.08 \mathrm{wt} . \%$ and relatively high leachate $\mathrm{pH}$ of 10.1 .

After carbonation, the acid neutralization capacity of the ash decreased from $4.2 \mathrm{mmol}-\mathrm{H}^{+} / \mathrm{g}$-ash to 3.9 and $3.3 \mathrm{mmol}-\mathrm{H}^{+} / \mathrm{g}$-ash for slowly carbonated and rapidly carbonated ash, respectively (data not shown), taken $\mathrm{pH} 7$ as endpoint.
Fig. 1 presents the leached concentrations of metals and As from the raw and carbonated APC residues. The concentrations of $\mathrm{Hg}$ and $\mathrm{Pb}$ leached from the raw APC residue, particularly the latter, were higher than the limit values $(0.05$ and $3 \mathrm{mg} / \mathrm{l}$, respectively) set by the Chinese identification standard for hazardous waste (State Environmental Protection Administration of China, 1996). Hence, the raw ash was classified as hazardous and might pose risk to environmental safety and public health following disposal (Chandler et al., 1997).

The leaching behavior of metals and As following carbonation could be categorized into three types: (raw residue $\approx$ carbonated residue) As (around the limit value), $\mathrm{Cd}$, and $\mathrm{Cu}$; (raw residue $>$ carbonated residue) $\mathrm{Hg}, \mathrm{Ni}$, $\mathrm{Pb}$ and $\mathrm{Zn}$; and (raw residue $<$ carbonated residue) $\mathrm{Cr}$ only. After carbonation, the leachability of $\mathrm{Hg}$ and $\mathrm{Pb}$ had become much lower than the corresponding limit values, and $\mathrm{Zn}$ was not even detected in the leachate of the carbonated residues. The carbonated residues would be then classified as non-hazardous for disposal. Based on similar observations, Ecke (2003b), Kim et al. (2003), and Meima and Comans (1999) proposed that carbonation could be used as a stabilization technique for $\mathrm{Pb}$ and $\mathrm{Zn}$ in APC residues or bottom ash. As reported in the following section, using Visual MINTEQ modeling, we examined whether the heavy metals in the APC residue were transformed into more stable carbonate or oxide forms following carbonation, or simply some hydroxides after $\mathrm{pH}$ changes.

\subsection{Change of metal speciation during the carbonation process}

Based on X-ray diffraction (XRD) analysis, He et al. (2006b) observed the increase of calcite and gypsum in the carbonated residues; however, heavy metal carbonates were not detected by XRD because of their trace amount. As such, it is also difficult to determine directly the changes of heavy metal species in the carbonated ash by other nondestructive analytical methods. Visual MINTEQ is an equilibrium speciation model used to calculate the equilibrium composition of aqueous solutions. Thus, it can be used to simulate aqueous speciation of the carbonated product subjected to a leaching system, although it is incapable of indicating reactions occurred in the carbonation process.

Fig. 2 illustrates the modeled pH-dependent leaching behavior of pure metal carbonates. Calculations for As and $\mathrm{Cr}$ are lacking since equilibrium data for their carbonates were not available. In a fully carbonated system, leachate $\mathrm{pH}$ of the APC residue could reach a value as low as 8.3 (Bone et al., 2003). Within this $\mathrm{pH}$ range $8-13$, carbonates of all heavy metals are relatively stable except $\mathrm{CdCO}_{3}$, which becomes significantly soluble at $\mathrm{pH}<10$. When $\mathrm{pH}$ further decreases to less than 6 , carbonates turn into soluble species following the order $\mathrm{CdCO}_{3}>\mathrm{NiCO}_{3}>\mathrm{Zn}$ $\mathrm{CO}_{3}>\mathrm{PbCO}_{3}>\mathrm{HgCO}_{3}>\mathrm{CuCO}_{3}$, suggesting carbonated 

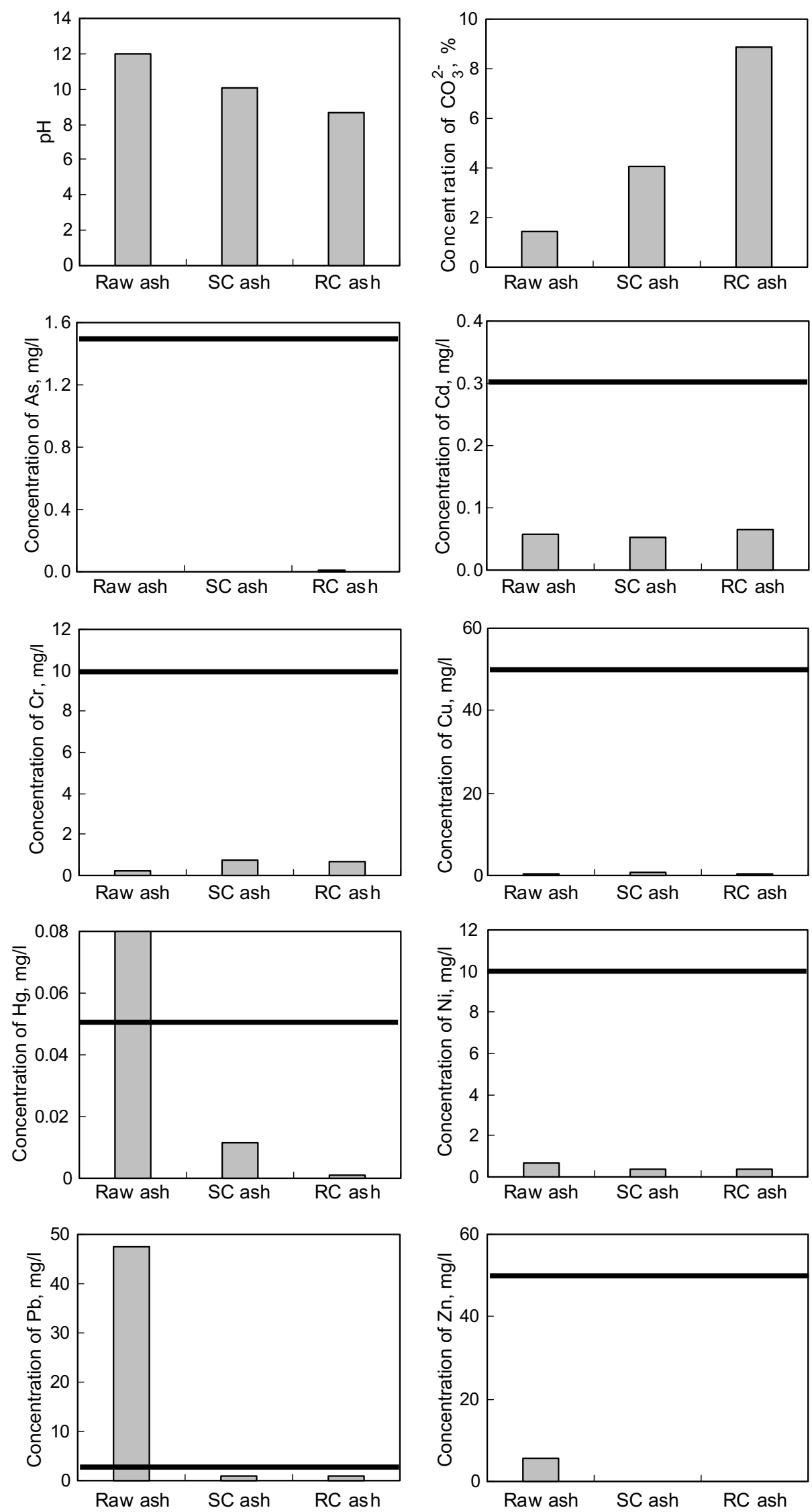

Fig. 1. Leaching characteristics of the raw, slowly carbonated (SC) and rapidly carbonated (RC) ash. The broad-brush solid line is the limit value set by the identification standard for hazardous waste (State Environmental Protection Administration of China, 1996). 


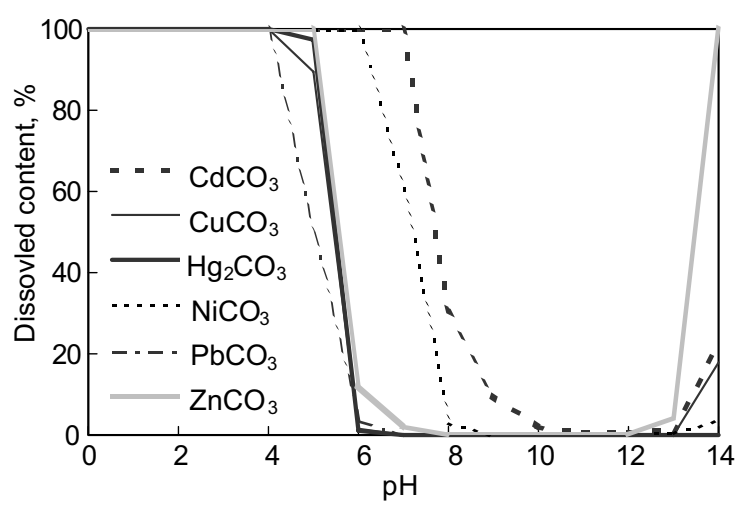

Fig. 2. Modeled pH-dependent leaching behavior of pure metal carbonates.

products will dissolve to a large extent when they encounter an acid shock.

In the leaching system of APC residue, much more complex results, as the combined effect of oxidation/reduction, hydration, competitive precipitation/dissolution and complexation, would be observed. Tables 2 and 3 summarize the modeling results of the carbonated residues under the extraction conditions of the regulatory leaching test. The release ratios of metals and As obtained by direct measurement and modeling were compared.

The major precipitates in the raw APC residue included $\mathrm{CaO}, \mathrm{CaCO}_{3}, \mathrm{SiO}_{2}, \mathrm{CaSO}_{4} \cdot 2 \mathrm{H}_{2} \mathrm{O}, \mathrm{Mg}_{3} \mathrm{Si}_{2} \mathrm{O}_{7} \cdot 2 \mathrm{H}_{2} \mathrm{O}$, and $\mathrm{Fe}_{2} \mathrm{O}_{3}$, among which the former three species and anhy- drite $\left(\mathrm{CaSO}_{4}\right)$ had been detected by XRD (He et al., 2004). After carbonation, the content of $\mathrm{CaCO}_{3}$ and gypsum $\left(\mathrm{CaSO}_{4} \cdot 2 \mathrm{H}_{2} \mathrm{O}\right)$ significantly increased, consistent with the XRD analytical results (He et al., 2006b).

Most of the modeling results, except for $\mathrm{Cd}$, were in agreement with the experimental results that the carbonated ash was of less leaching toxicity. Predicted Cd concentration was significantly discrepant with the observed value. According to Visual MINTEQ, Cd could completely release from the rapidly carbonated ash at $\mathrm{pH}$ 8.7; however, only $1.14 \%$ of $\mathrm{Cd}$ was leached from the ash in the real extraction system. Apul et al. (2005) and Meima and Comans (1998) had also found that the predicted Cd concentrations could be one order of magnitude higher than the measured concentrations even when a surface complexation model by hydrous ferric oxide (HFO) and aluminum (hydr)oxides was included. The use of a surface precipitation model did not significantly improve the match between observed and predicted concentrations either. The modeling results for $\mathrm{Cd}$ are still inconclusive.

As the model predicted, heavy metals of the carbonated residues precipitated in the leaching system mainly as hydroxide or oxide, $\mathrm{Cd}_{4}(\mathrm{OH})_{6} \mathrm{SO}_{4}, \mathrm{Cr}_{2} \mathrm{O}_{3}, \mathrm{Ni}(\mathrm{OH})_{2}$, $\mathrm{Pb}_{2}(\mathrm{OH})_{3} \mathrm{Cl}, \mathrm{ZnO}$, respectively. $\mathrm{As}, \mathrm{Cu}, \mathrm{Hg}$ formed insoluble $\mathrm{Ca}_{3}\left(\mathrm{AsO}_{4}\right)_{2} \cdot 4 \mathrm{H}_{2} \mathrm{O}$ (slowly carbonated ash) or $\mathrm{Mn}_{3}-$ $\left(\mathrm{AsO}_{4}\right)_{2} \cdot 8 \mathrm{H}_{2} \mathrm{O}$ (rapidly carbonated ash), $\mathrm{CuFeO}_{2}$ and $\mathrm{Hg}$ in the elute. No heavy metal carbonates precipitated, since $\mathrm{CO}_{3}^{2-}$ preferentially reacted with $\mathrm{Ca}^{2+}$ and $\mathrm{Mg}^{2+}$ to form $\mathrm{CaCO}_{3}$ and $\mathrm{MgCO}_{3}$ and precipitated from the leachate.

Table 2

Species of major precipitates in the raw and carbonated APC residues based on modeling results

\begin{tabular}{|c|c|c|c|c|c|}
\hline \multicolumn{2}{|c|}{ Raw ash $(\mathrm{pH}=12.0)$} & \multicolumn{2}{|c|}{ Slowly carbonated ash $(\mathrm{pH}=10.1)$} & \multicolumn{2}{|c|}{ Rapidly carbonated ash $(\mathrm{pH}=8.7)$} \\
\hline Major precipitates & Concentration $(\mathrm{mol} / \mathrm{l})$ & Major precipitates & Concentration $(\mathrm{mol} / \mathrm{l})$ & Major precipitates & Concentration $(\mathrm{mol} / \mathrm{l})$ \\
\hline $\mathrm{CaO}$ & $4.91 \mathrm{E}-01$ & & & & \\
\hline $\mathrm{Fe}_{2} \mathrm{O}_{3}$ & $2.60 \mathrm{E}-02$ & & & & \\
\hline $\mathrm{SiO}_{2}$ & $2.41 \mathrm{E}-01$ & $\mathrm{SiO}_{2}$ & $2.62 \mathrm{E}-01$ & $\mathrm{SiO}_{2}$ & $2.63 \mathrm{E}-01$ \\
\hline $\mathrm{Mg}_{3} \mathrm{Si}_{2} \mathrm{O}_{7} \cdot 2 \mathrm{H}_{2} \mathrm{O}$ & $1.86 \mathrm{E}-02$ & $\mathrm{Mg}_{3} \mathrm{Si}_{2} \mathrm{O}_{7} \cdot 2 \mathrm{H}_{2} \mathrm{O}$ & $1.86 \mathrm{E}-02$ & $\mathrm{Mg}_{3} \mathrm{Si}_{2} \mathrm{O}_{7} \cdot 2 \mathrm{H}_{2} \mathrm{O}$ & $1.85 \mathrm{E}-02$ \\
\hline $\mathrm{CaSO}_{4} \cdot 2 \mathrm{H}_{2} \mathrm{O}$ & $8.70 \mathrm{E}-03$ & $\mathrm{CaSO}_{4} \cdot 2 \mathrm{H}_{2} \mathrm{O}$ & $1.10 \mathrm{E}-02$ & $\mathrm{CaSO}_{4} \cdot 2 \mathrm{H}_{2} \mathrm{O}$ & $1.07 \mathrm{E}-02$ \\
\hline \multirow[t]{2}{*}{$\mathrm{CaCO}_{3}$} & $2.38 \mathrm{E}-02$ & $\mathrm{CaCO}_{3}$ & $6.79 \mathrm{E}-02$ & $\mathrm{CaCO}_{3}$ & $1.48 \mathrm{E}-01$ \\
\hline & & $\mathrm{MgCO}_{3}$ & $1.73 \mathrm{E}-02$ & $\mathrm{MgCO}_{3}$ & $1.73 \mathrm{E}-02$ \\
\hline
\end{tabular}

Table 3

Heavy metals and As released from the carbonated APC residues based on experimental and modeling results

\begin{tabular}{|c|c|c|c|c|c|c|}
\hline & \multicolumn{3}{|l|}{ Slowly carbonated ash } & \multicolumn{3}{|l|}{ Rapidly carbonated ash } \\
\hline & Measured release $(\%)$ & Modeled release $^{\mathrm{a}}(\%)$ & Precipitates & Measured release $(\%)$ & Modeled release $^{\mathrm{a}}(\%)$ & Precipitates \\
\hline As & 0.00 & 0.29 & $\mathrm{Ca}_{3}\left(\mathrm{AsO}_{4}\right)_{2} \cdot 4 \mathrm{H}_{2} \mathrm{O}$ & 0.14 & 1.01 & $\mathrm{Mn}_{3}\left(\mathrm{AsO}_{4}\right)_{2} \cdot 8 \mathrm{H}_{2} \mathrm{O}$ \\
\hline $\mathrm{Cd}$ & 0.91 & 4.45 & $\mathrm{Cd}_{4}(\mathrm{OH})_{6} \mathrm{SO}_{4}$ & 1.14 & 100 & - \\
\hline $\mathrm{Cu}$ & 0.58 & 0.00 & $\mathrm{CuFeO}_{2}$ & 0.54 & 0.00 & $\mathrm{CuFeO}_{2}$ \\
\hline $\mathrm{Hg}$ & 0.30 & 0.25 & $\mathrm{Hg}$ & 0.03 & 0.26 & $\mathrm{Hg}$ \\
\hline $\mathrm{Ni}$ & 2.98 & 0.00 & $\mathrm{Ni}(\mathrm{OH})_{2}$ & 2.92 & 0.28 & $\mathrm{Ni}(\mathrm{OH})_{2}$ \\
\hline
\end{tabular}

\footnotetext{
${ }^{\text {a }}$ As predicted in Visual MINTEQ.
} 
Future experiments to define the effect of surface complexation and precipitation on the release rates of heavy metals are desirable to improve the match between observed and predicted concentrations.

\subsection{Effect of carbonation and $\mathrm{pH}$ on the leaching behavior of the APC residues}

Fig. 3 demonstrates the $\mathrm{pH}$ varying test results of the raw, slowly carbonated and rapidly carbonated residue samples. Regardless of carbonation, all residue samples possessed similar $\mathrm{pH}$-dependent leaching behavior of individual metals and As.

Although complex reactions might occur in carbonation and leaching processes, the final $\mathrm{pH}$ of leachate, a result of combined effects of all reactions/processes, presents the major index influencing leaching equilibrium. As shown in Fig. 3, the heavy metals and As release curves can be divided into two main groups in the range $\mathrm{pH} 0-13$ : $\mathrm{V}$ shaped $(\mathrm{Cd}, \mathrm{Cr}, \mathrm{Hg}, \mathrm{Ni}, \mathrm{Pb}$ and $\mathrm{Zn}$ ) and $\mathrm{L}$ shaped (As and $\mathrm{Cu}$ ). With final suspension $\mathrm{pH}$ decreasing from 12.0 to 8.7 , the concentration ranges of $\mathrm{As}$ and $\mathrm{Cu}$ are located
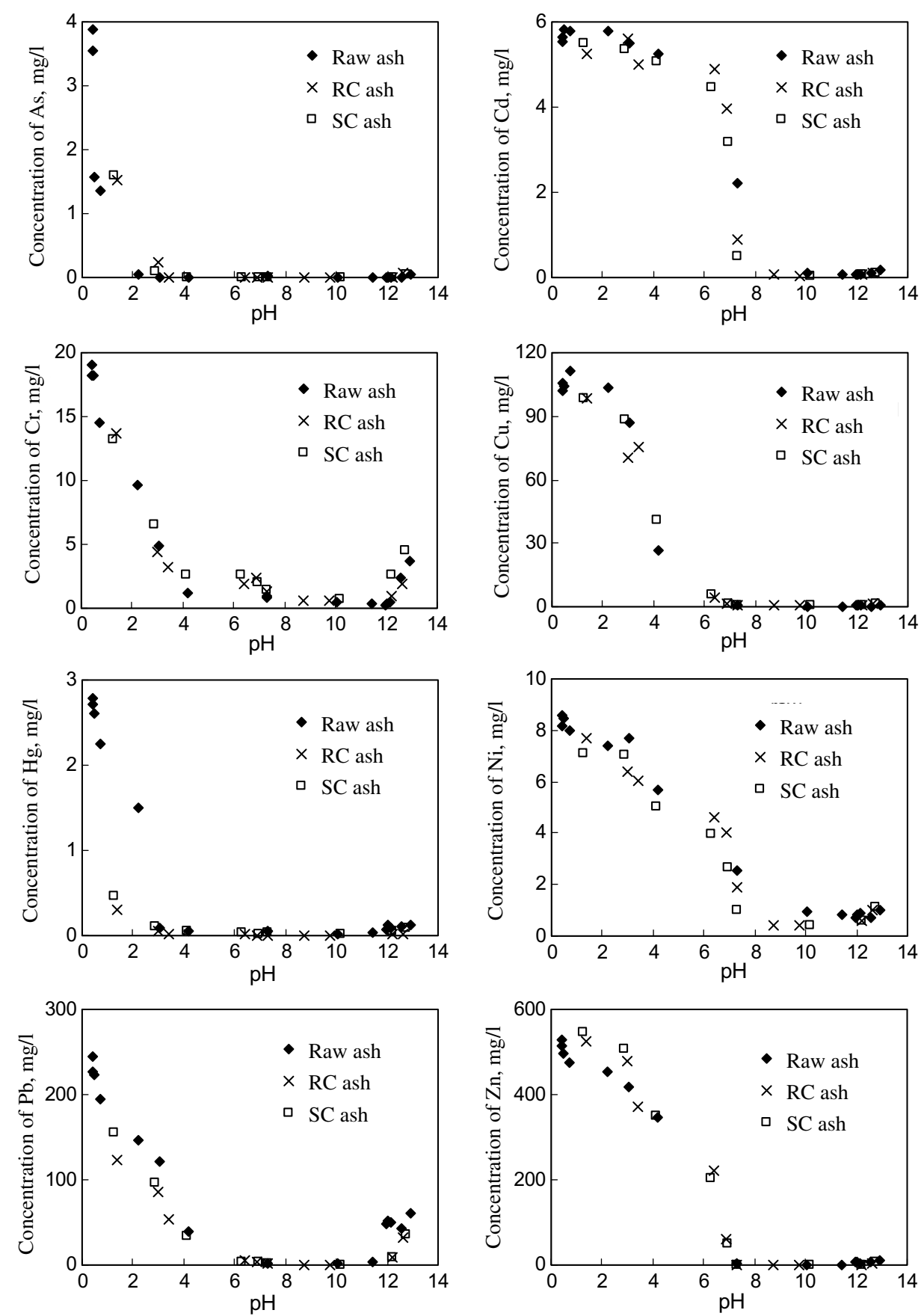

Fig. 3. pH-dependent leaching behavior of the raw, slowly carbonated (SC) and rapidly carbonated (RC) ash. 


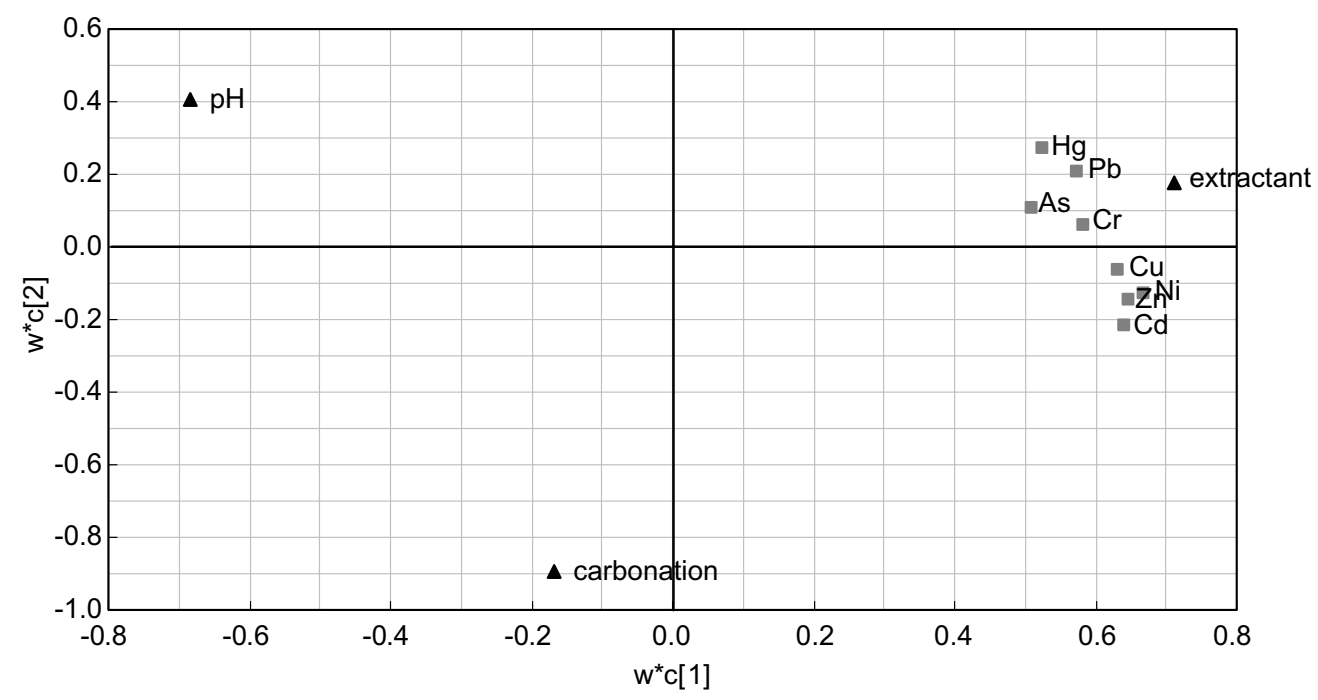

Fig. 4. PLS loading plot of the first and second principal components using data from $\mathrm{pH}$ varying tests of the raw and carbonated ashes.

at the alkaline side of the $\mathrm{L}$ curves, showing only weak fluctuation during carbonation. In the $\mathrm{pH}$ range of $8-13, \mathrm{Cd}$, $\mathrm{Ni}, \mathrm{Hg}, \mathrm{Pb}$, and $\mathrm{Zn}$ leaching is situated on the right leg of the $\mathrm{V}$ curves, so their leaching concentrations decreased as $\mathrm{pH}$ lowers (or with carbonation). On the contrary, the $\mathrm{Cr}$ leaching is located in the left part of the $\mathrm{V}$ curve, where leaching concentration increases when $\mathrm{pH}$ approaches 8.7 when coming from more alkaline conditions.

Similar to the modeled $\mathrm{pH}$-dependent result of pure metal carbonates (Fig. 2), within the $\mathrm{pH}$ range 8-11, As and heavy metals were relatively stable. When $\mathrm{pH}$ decreased to less than 7, however, a significant increase of $\mathrm{Cd}, \mathrm{Ni}$, and $\mathrm{Zn}$ leaching was observed. At $\mathrm{pH} \mathrm{6,} \mathrm{Cu}$ and $\mathrm{Pb}$ became more leachable. $\mathrm{As}, \mathrm{Cr}$, and $\mathrm{Hg}$ were relatively stable under weak acidic conditions. From the regulatory viewpoint, the carbonated APC residue was not really "stabilized" and could not be disposed of directly, with regard to its release potential under acid shock $(\mathrm{pH}<6-7)$. On the other hand, rapid carbonation $(10 \mathrm{~h})$ or slow carbonation (7 d) might be favorably used as a simple pretreatment process to control pollution before the final treatment and disposal of ash, by decreasing $\mathrm{pH}$ of the carbonated residue to $8-11$.

\subsection{PLS modeling}

The PLS analysis is a regression algorithm relating input and output samples $\left(x_{i}, y_{i}\right)$ by a linear multivariate model (Nadler and Coifman, 2005). It obtains PLS-weights for the variables. The weights for the $X$-variables indicate the importance of these variables, how much they "in a relative sense" participate in the modeling of $Y$, while the weights for the $Y$-variables indicate which $Y$-variables are modeled in the respective PLS model dimension. When these weights are plotted in a PLS loading plot, we obtain a picture showing the relationships between $X$ and $Y$-variables, which $X$-variables are important, and which $Y$-variables are related to which $X$, etc. (Umetrics AB, 2005).
In this study, the PLS modeling taking into account extractant concentration, carbonation level, and leachate $\mathrm{pH}$, resulted in two principal components comprising $71 \%$ and $2.5 \%$ of the data variation. The first principal component dominantly explained data variation.

The loading plot (Fig. 4) illustrates the impact of various factors (extractant concentration, leachate $\mathrm{pH}$, and carbonation level) on the response variables (concentration of metals and As). The metals and As release depended significantly on the extractant (acid or alkaline) concentration and leachate $\mathrm{pH}$. Compared to the positive correlation between extractant concentration and heavy metals release, leachate $\mathrm{pH}$ (which is the combining result of the extractant concentration, carbonation level, and leaching process), was negatively correlated to metals leaching concentration. The carbonation level dominating the second principal component, which covered only $2.5 \%$ of the data variation, was inconclusive.

All metals and As showed similar variation. If further subdivided according to their $X$-weight, $\mathrm{Cu}, \mathrm{Cd}, \mathrm{Ni}$, and $\mathrm{Zn}$ were more significantly influenced by extractant and leachate $\mathrm{pH}$. This observation corresponds to the results shown in Fig. 3, that these metals were more acid-leachable, with rising release when $\mathrm{pH}$ fell to less than 7. As, $\mathrm{Hg}, \mathrm{Cr}$, and $\mathrm{Pb}$ were relatively resistant to $\mathrm{pH}$ decrease, whose leachability increased at $\mathrm{pH}$ less than 4-6.

\section{Conclusions}

After rapid and slow carbonation, the $\mathrm{CO}_{3}^{2-}$ content in the APC residue increased from $1.43 \mathrm{wt} . \%$ to $8.85 \mathrm{wt} . \%$ and $4.08 \mathrm{wt} . \%$, respectively, and the leachate $\mathrm{pH}$ of the rapidly and slowly carbonated ash decreased to 8.7 and 10.1, respectively. The leaching toxicity test showed that carbonation could significantly immobilize heavy metals $(\mathrm{Hg}, \mathrm{Pb}$ and $\mathrm{Zn}$ ) and turned the hazardous materials into "non-hazardous" waste. A slight decrease of $\mathrm{Ni}$ leaching and increase of $\mathrm{Cr}$ was found, while $\mathrm{Cd}$ and $\mathrm{Cu}$ leaching 
concentration remained stable, all of them were far below the limit values. However, the so-called stabilization was mainly due to the decrease of leachate $\mathrm{pH}$ controlled by the carbonation in the short-term, which finally influenced the solubility of metals, according to the results of $\mathrm{pH}$ varying test, PLS analysis, and Visual MINTEQ modeling. Although the long-term leaching potential of the carbonated APC residue was of concern when the residue was under an acid shock, carbonation in air via water spraying could be applied as a temporary stabilization stage during transportation and storage before final disposal.

\section{Acknowledgments}

We thank Shanghai Council of Science and Technology for the financial support through the project "Research on beneficial use of MSW incineration residues and its demonstration project" (032312043).

\section{References}

Allison, J.D., Brown, D.S., Novo-Gradac, K.J., 1991. MINTEQA2/ PRODEFA2, A Geochemical Assessment Model for Environmental Systems: Version 3.0 User's Manual. Environmental Research Laboratory, Georgia, USA.

Apul, D.S., Gardner, K.H., Eighmy, T.T., Fällman, A.M., Comans, R.N.J., 2005. Simultaneous application of dissolution/precipitation and surface complexation/surface precipitation modeling to contaminant leaching. Environmental Science and Technology 39, 5736-5741.

Astrup, T., Mosbæk, H., Christensen, T.H., 2006. Assessment of longterm leaching from waste incineration air-pollution-control residues. Waste Management 26, 803-814.

Bone, B.D., Knox, K., Picken, A., Robinson, H.D., 2003. The effect of carbonation on leachate quality from landfilled municipal solid waste (MSW) incinerator residues. Proceedings Sardinia 2003, Ninth International Waste Management and Landfill Symposium, 6-10 October 2003. S. Margherita di Pula, Cagliari, Italy.

Chandler, A.J., Eighmy, T.T., Hartlén, J., Hjelmar, O., Kosson, D.S., Sawell, S.E., van der Sloot, H.A., Vehlow, J., 1997. Municipal Solid Waste Incinerator Residues. Elsevier, The Netherlands.

Chimenos, J.M., Fernández, A.I., Nadal, R., Espiell, F., 2000. Short-term natural weathering of MSWI bottom ash. Journal of Hazardous Materials B79, 287-299.

Ecke, H., Menad, N., Lagerkvist, A., 2003a. Carbonation of municipal solid waste incineration fly ash and the impact on metal mobility. Journal of Environmental Engineering-ASCE 129, 435-440.

Ecke, H., 2003b. Sequestration of metals in carbonated municipal solid waste incineration (MSWI) fly ash. Waste Management 23, 631-640.

Eighmy, T.T., Eusden, J.D., Krzanowski, J.D., Domingo, D.S., Stämpfli, D., Martin, J.R., Erickson, P.M., 1995. Comprehensive approach toward understanding element speciation and leaching behavior in municipal solid waste incineration electrostatic precipitator ash. Environmental Science and Technology 29, 629-646.

Freyssinet, P., Piantone, P., Azaroual, M., Itard, Y., Clozel-Leloup, B., Guyonnet, D., Baubron, J.C., 2002. Chemical changes and leachate mass balance of municipal solid waste bottom ash submitted to weathering. Waste Management 22, 159-172.

Garrabrants, A.C., Sanchez, F., Kosson, D.S., 2004. Changes in constituent equilibrium leaching and pore water characteristics of a Portland cement mortar as a result of carbonation. Waste Management 24, 1936 .

Gervais, C., Garrabrants, A.C., Sanchez, F., Barna, R., Moszkowicz, P., Kosson, D.S., 2004. The effects of carbonation and drying during intermittent leaching on the release of inorganic constituents from a cement-based matrix. Cement and Concrete Research 34, 119131.

Gustafsson, J.P., 2005. Visual MINTEQ ver 2.32. < http://www.lwr.kth.se/ english/oursoftware/vminteq/>.

He, P.J., Zhang, H., Zhang, C.G., Lee, D.J., 2004. Characteristics of air pollution control residues of MSW incineration plant in Shanghai. Journal of Hazardous Materials B116, 229-237.

He, P.J., Zhang, H., Shao, L.M., Lee, D.J., 2006a. Leaching of carbonated air pollution control residues using compliance leaching tests. Journal of Environmental Quality 35, 442-449.

He, P.J., Cao, Q.K., Shao, L.M., Lee, D.J., 2006b. Aging of air pollution control residues from municipal solid waste incinerator: role of water content on metal carbonation. Science of the Total Environment 359, 26-37.

Kim, S.Y., Matsuto, T., Tanaka, N., 2003. Evaluation of pre-treatment methods for landfill disposal of residues from municipal solid waste incineration. Waste Management and Research 21, 416-423.

Li, X.D., Poon, C.S., Sun, H., Lo, I.M.C., Kirk, D.W., 2001. Heavy metal speciation and leaching behaviors in cement based solidified/stabilized waste materials. Journal of Hazardous Materials A82, 215230.

Meima, J.A., Comans, R.N.J., 1998. Application of surface complexation/ precipitation modeling to contaminant leaching from weathered municipal solid waste incinerator bottom ash. Environmental Science and Technology 32, 688-693.

Meima, J.A., Comans, R.N.J., 1999. The leaching of trace elements from municipal solid waste incinerator bottom ash at different stages of weathering. Applied Geochemistry 14, 159-171.

Meima, J.A., van der Weijden, R.D., Eighmy, T.T., Comans, R.N.J., 2002. Carbonation processes in municipal solid waste incinerator bottom ash and their effect on the leaching of copper and molybdenum. Applied Geochemistry 17, 1503-1513.

Nadler, B., Coifman, R.R., 2005. Partial least squares, beer's law and the net analyte signal: statistical modeling and analysis. Journal of Chemometrics 19, 45-54.

Polettini, A., Pomi, R., 2004. The leaching behavior of incinerator bottom ash as affected by accelerated ageing. Journal of Hazardous Materials B113, 209-215.

Sanchez, F., Gervais, C., Garrabrants, A.C., Barna, R., Kosson, D.S., 2002. Leaching of inorganic contaminants from cement-based waste materials as a result of carbonation during intermittent wetting. Waste Management 22, 249-260.

State Environmental Protection Administration of China, 1996. Identification Standard for Hazardous Wastes - Identification for Extraction Procedure Toxicity, GB50853-1996. State Environmental Protection Administration of China, Beijing (in Chinese).

State Environmental Protection Administration of China, 1997. Test Method Standard for Leaching Toxicity of Solid Wastes - Roll Over Leaching Procedure, GB5086.1-1997. State Environmental Protection Administration of China, Beijing (in Chinese).

Umetrics AB, 2005. User's Guide to SIMCA-P, SIMCA-P+. Umetrics AB, Sweden. http://www.umetrics.com.

van der Bruggen, B., Vogels, G., Van Herck, P., Vandecasteele, C., 1998. Simulation of acid washing of municipal solid waste incineration fly ashes in order to remove heavy metals. Journal of Hazardous Materials 57, 127-144.

van der Sloot, H.A., Heasman, L., Quevauviller, P., 1997. Harmonization of Leaching/Extraction Tests. Elsevier, The Netherlands.

Van Gerven, T., Moors, J., Dutré, V., Vandecasteele, C., 2004. Effect of $\mathrm{CO}_{2}$ on leaching from a cement-stabilized MSWI fly ash. Cement and Concrete Research 34, 1103-1109.

Van Gerven, T., Van Keer, E., Arickx, S., Jaspers, M., Wauters, G., Vandecasteele, C., 2005. Carbonation of MSWI-bottom ash to decrease heavy metal leaching, in view of recycling. Waste Management 25, 291-300.

Van Gerven, T., Cornelis, G., Vandoren, E., Vandecasteele, C., Garrabrants, A.C., Sanchez, F., Kosson, D.S., 2006. Effects of progressive 
carbonation on heavy metal leaching from cement-bound waste. AIChE Journal 52, 826-837.

van Herck, P., van der Bruggen, B., Vogels, G., Vandecasteele, C., 2000. Application of computer modeling to predict the leaching behavior of heavy metals from MSWI Fly ash and comparison with a sequential extraction method. Waste Management 20, 203-210.
Walton, J.C., Bin-Shafique, S., Gutierrez, N., Smith, R., Tarquin, A., 1997. Role of carbonation in transient leaching of cementitious wasteforms. Environmental Science and Technology 31, 2345-2349.

Yu, Q., Nagataki, S., Lin, J., Saeki, T., Hisada, M., 2005. The leachability of heavy metals in hardened fly ash cement and cement-solidified fly ash. Cement and Concrete Research 35, 1056-1063. 